\title{
METAPHORS IN SCIENTIFIC AND TECHNICAL LANGUAGES: CHALLENGES AND PERSPECTIVE ${ }^{1}$
}

\author{
(Metáforas em linguagens técnicas e científicas: \\ desafios e perspectivas)
}

\author{
Maria José Bocorny FinATTO \\ (Universidade Federal do Rio Grande do Sul - BRAZIL)
}

\begin{abstract}
Resumo: $O$ objetivo deste artigo é mostrar, de um modo conciso, como diferentes estudos sobre metáfora podem convergir, positivamente, para uma percepção lingüiśtico-cognitiva do fenômeno, a qual supera uma visão meramente estilística. Relata-se, com destaque, a pesquisa de Huang (2005) sobre a metáfora no texto científico de Medicina que trata sobre AIDS. Essa pesquisa, em seus resultados e dificuldades, serve como um exemplo para o tratamento da metáfora em Terminologia e em estudos do texto especializado. $O$ artigo conclui que a metáfora é um dos fenômenos que integram a comunicação técnico-científica e que, a despeito da complexidade de sua abordagem, deve ser investigado também em estudos de Terminologia.
\end{abstract}

Palavras-chave: metáforas; terminologias; linguagens especializadas; textos científicos.

Abstract: This article aims to show, in a summarized way, how different studies on metaphor can positively converge to a cognitive-linguistic perception of this phenomenon. This perception surpasses a merely stylistic vision of the metaphor. The paper also reports the research that was done by Huang (2005) about metaphors in scientific texts of Medicine, which is related to the topic of AIDS. The results and difficulties of Huang's research have given examples in the treatment of the theme of metaphor in Terminology and in studies of scientific texts. It is concluded that metaphor is one of the phenomena that make part of the technical and scientific communication and, because of the complexity in approaching such topic, it must also be investigated in Terminology.

Key-words: metaphors; terminology; specialized languages; scientific texts.

1. For further information on terminological history of Chemistry, see FINATTO, 2001. 


\section{INTRODUCTION}

The study of metaphor, in its origin, was not part of the language studies; it belonged to Rhetoric. According to Lopes (1987), who reviewed the history of Rhetoric as a discipline since Ancient Rhetoric, the "art of saying and persuading" became, only and unfortunately, the "art of frill." During the Enlightenment, Rhetoric stopped being an autonomous discipline, especially in France. For the École Normale, for instance, this affiliate discipline became Literature. Thus, the range of studies denominated "Rhetoric" started being understood mainly as a study of figures of speech. Metaphor was among these figures, whose main function was to make the message more impactive to the interlocutor, showing and asseverating ability, talent and elegance in communication. From this "artistic" conception of the use of language derive a number of grammatical and linguistic studies on metaphors, especially in Stylistics.

At first sight, in this older perspective on metaphors as "stylistic" elements, scientific language and metaphors were completely incompatible elements. After all, because of an ideal of univocity and precision, emphatically cultivated in the beginning of the XX century, "ornaments", such as metaphors, had no space in scientific language. This ideal of expression, without subjectivity and any appreciative or aesthetic marks from its enunciator, had already been accepted as a sine qua non condition for scientificity. The birth of Modern Chemistry is an example of it. Lavoisier's project to make Chemistry a "serious" science, in opposition to Physics, a model science in XVIII century, is one of the most scathing testimonials in the search for this ideal. It was necessary that Chemistry was freed from expressions and terminologies that were associated to Alchemy. It was essential that Chemistry had more objectivity and conformation of its specific terms. Then, Lavoisier established a whole new standardized nomenclature for substances and equipments and indicated that alchemic terms should be banned from the vocabulary of this new science that he was annunciating and representing.

In the $20^{\text {th }}$ century, among many more recent authors, the philosopher of sciences Bunge (1961) identified that sciences' expression, precisely for being scientific, imply control of language. Thus, scientific language involves: a) linguistic accuracy, since ambiguity, imprecision and obscurity should be minimal; b) empiric interpretability; c) representativity and semantic 
simplicity (our emphasis), being important to put away presuppositions. Then, in the situation of communication of and in sciences, to understand what is being said and about what, "a directive of formulation of exact and precise enunciations, is imperative" (Schaff 1968: 343). In this scenario, such as in Antiquity, metaphor remains an "ornament" and still remains as something undesirable in sciences' communication.

Accentuating this ancient conception of cientificity and metaphor, sometimes a symbol of a very superficial understanding on the functioning of language, the aim of this paper is to emphasize that current studies on metaphors are distant from a rhetoric-figurative conception. The major idea of this paper is, then, to show, even in a succinct way, how different studies on metaphors can converge, positively, for a linguistic-cognitive perception of the phenomenon and its role in scientific communication. This is a role that, as we will see, goes against this ancient understanding. We will take as reference, to demonstrate some results, a research carried by Huang (2005) on metaphors in scientific texts of Medicine. This paper is only an example among others for the treatment of metaphors in Terminology and in studies that involve specialized texts.

Briefly, Terminology is a relatively new area of studies in Brazil, which is dedicated to the recognition of phenomena which integrate the technicalscientific communication according to a linguistic, social, cognitive and communicative perspective.

\section{NEW CONCEPTIONS ON METAPHORS}

Literary critic Salvatore d'Onofrio has already recognized the existence of two possible approaches on metaphor: the rhetoric conception and the semantic conception. The rhetoric conception is the one Aristotle's Rhetoric and other philosophers from antiquity have already described: a verbal figure with "decorative function, being a vestment to cover the naked expression of a thought or a cosmetic to beautify the discourse" (1980: 150). In the perspective of semantics, according to what he explained, metaphors would be a predication in which two terms belong to different semantic fields. This author, who well represents the combination and the acceptance of the metaphor studies by Literature since the École mentioned before, is jocose when adds, referring to the notion of predication, a comment that 
qualifies it as an "impertinent predication." His major contribution, in our opinion, is to point out the semantic, linguistic and logic perspectives of this issue, emphasizing that metaphor is an important element that contributes to the revitalization of the human language. Ultimately, this author presents metaphor as something positive and not as an undesirable element that must be "banned".

At the same time of this new direction shown by literary studies, Lakoff \& Johnson (2002) established an even more differentiated view of metaphor. For these authors, metaphors are part of our everyday life. And, according to what they say, this integration is so intense that we live immersed in metaphorical universes in a way that we cannot even notice. The metaphoric thought, as they explained, is a mechanism of thought that is constantly used for communication among people and, moreover, to the comprehension of the world.

According to the authors, our conceptual system is metaphorical in nature. This system, particular for each individual and of which he usually does not have consciousness, would be responsible for designing, structuring and implementing metaphors. Lakoff \& Johnson also spread the idea that we can better understand the configuration and functioning of this conceptual system by considering some aspects of our daily lives - and one of them would be language. Here, as it is easy to understand, metaphor ceases to be "decoration" to become an inherent condition in the organization of the human perception of reality.

From this quite different conception on metaphor and its role in language, diffused by Cognitive Linguistics, the issue started raising interest for different scholars and researchers on Terminology. Among terminologists, we highlight the contribution of Temmerman (2000), since much of the work of this author is based on a number of works by Lakoff \& Johnson.

Temmerman has taken as reference the idea that a conceptual system also exists in a given area of science or knowledge and that this system can be understood and perceived by the description of specific features, such as metaphor, in the language that runs it. From the combination between the studies of language, terminology and the perspective of metaphorization as a comprehensive and expressive feature inherent to Humanity, we are 
seeing, finally, a greater reception of the theme by researchers in specialized languages.

\section{MetAPHORS IN SCIENTIFIC TEXTS}

Lakoff \& Johnson (2002), mentioned before, believe that metaphorical thinking is directly related to cognition. It means that the manners in which we understand, know the world and acquire knowledge are essential for the composition and also for our understanding on how metaphor happens. Thus, metaphorization depends on how we conceive the world, and the opposite direction is valuable too.

Temmerman (2000), adhering to these conceptions, believes that the metaphoric thought, within science, is inherently and historically established, being responsible for the understanding of new types of facts, processes or other categories of knowledge. Metaphoric thought is usually used to explain these new situations with the help of a creative capacity that human beings have. These thoughts are, therefore, based on human experiences.

What Rita Temmerman brings that is novelty for Terminology is her project to describe how metaphoric thought is expressed, how it is used in the designation and classification under the areas of scientific knowledge and technology. Her goal is to demonstrate how this reasoning leaves its traces in language, taking into account the example of the language of Biology, notaly the sub-area of Genetics.

The point Temmerman sought to reach was to spotlight how metaphoric neologisms that integrate a specific terminology are related to the process of creative analogical thinking. These neologisms, or neolexicalizations, would be a result of deep analogies used to creative understanding or didactic purposes. It is from this process as considered by the author that come two types of metaphors: the didactic metaphor (which only serves for a teaching situation) and creative metaphor (which originates neologisms that can be consolidated and accepted as "technical terms" of a specialized language).

However, Temmerman point out an important qualification for the study of metaphor in the scientific language scenario: she indicates the uppercase importance of studying, before anything else, the history of the 
specialty area in focus. The diachrony, as she advocates, will play a key role in the constitution of metaphors in four different historical aspects: social, technical, cognitive and terminological aspects. The social aspect comprises the influence of the circumstances of a time when the expertise area is developed. All these aspects, in different ways, will influence the language that the area or science will use.

In the case of Biology, according to the author, it seems that there was a dispute for power between Americans and Germans, which resulted in parallel studies with different bases. This dispute influenced the way the research took and naturally this situation of polarity, between Germanic studies and U.S. studies, will be reflected on the way language is employed. But the technical aspect involved technologies that work in favor of the area. The most noteworthy example of technology is the use of computers, which increased the storage capacity of information and provided a considerable advance in Biology, especially regarding the researches on the human genome. A plenty of data to consider is a situation that also will reflect on the facet of communication and language employed in that field.

Regarding the cognitive aspect, as explained by Temmerman, what most influenced this field was analogical thought. This type of reasoning would be responsible for assignments such as, for example, "messenger DNA." Finally, the terminological issue is the evolution of terminology, in its transformation, with special attention to the genesis of neologisms. Amongst the different neologisms that the author notes, she considered important to distinguish those with origin in scientific metaphors, particularly looking for their source domain.

Temmerman's work summarized here, illustrates the beginnings of the studies of this theme in Terminology. After this brief review about the beginning of the new theme in Terminology, the research area in which we are included ${ }^{2}$, we start dealing with a particular research initiative. This initiative, developed by Huang (2005), incorporated the concepts of Lakoff \& Johnson, Temmerman and Corpus Linguistics mentioned before. Huang's objective was to describe and to classify the presence of metaphors in articles published in journals of medicine that deal with AIDS. This work will be included here because we believe that, despite any possible

2. For further information about our studies and works in theoretical and applied Terminology, we suggest a visit to the website www.ufrgs.br/termisul. 
mistakes, it had the undeniable merit of bringing the subject to the setting of Terminology, as developed in Brazil.

\section{Metaphors in MEDiCAL TEXTS ON AIDS}

The work of Huang (2005) aims at contributing to the description of the medical language on AIDS. This work, in a summarized and schematic way, can be described as follows:

1) It examines the incidence of potentially metaphorical expressions (PME) in a corpus composed of texts published in Revista da Associação Médica do Brasil, from 1984 to 2002.

2) It establishes the benchmark concept of potentially metaphorical expression (PME) based on literature review.

3) PME is seen by the author as a statement with sintagmatic presentation formed by at least one "technical" term from Medicine plus a lexical word (noun, adjective or verb) or a verbal phrase. The starting point for the observation of these expressions was a list of keywords related to AIDS.

4) This list was composed from the keywords listed in the corpus and included the terminology of an AIDS glossary produced by Ministério da Saúde do Brasil (Ministry of Brazilian Health). Thus, the author examines the "metaphoric environment" expressed in the vicinity of a set of 113 terms related to the disease.

5) With the tool Wordlist, of the software package WordSmith Tools, and with the theoretical and methodological principles of Corpus Linguistics, the contexts of occurrence of these terms were listed and examined. The tool identified 2.578 contexts of PME. Within these contexts, Huang identified 87 standards of achievement.

6) Her paper concluded that the most occurrent type of PME is PERSONIFICATION.

7) At the end of the paper, she makes some considerations about a stigmatizing effect attributed by some authors, critics of medical language, to the function of metaphors in texts about AIDS. 
In the table below, we can see a segment of the findings Huang has reached. The contexts contain PME terms related to AIDS and CD4:

\begin{tabular}{|c|c|}
\hline TERM & Potentially Metaphorical Expressions (PMEs) \\
\hline \multirow{9}{*}{ AIDS } & 1. inquietação promovida pela AIDS (the concern caused by AIDS) \\
\hline & 2. tempos de AIDS (times of AIDS) \\
\hline & 3. história natural da AIDS (natural history of AIDS) \\
\hline & 4. impacto psicossocial desencadeado pela AIDS (psychosocial impact of AIDS) \\
\hline & $\begin{array}{l}\text { 5. será porque a AIDS atingiu mortalmente personalidades mundanas? (it is because } \\
\text { AIDS killed mundane personalities?) }\end{array}$ \\
\hline & 6. a AIDS está ganbando a corrida (AIDS is winning the race) \\
\hline & $\begin{array}{l}\text { 7. o uso de drogas (...) poderia acelerar o curso da AIDS (the use of drugs }[. . .] \text { could } \\
\text { accelerate the course of AIDS) }\end{array}$ \\
\hline & 8. desenvolvimento da AIDS (development of AIDS) \\
\hline & $\begin{array}{l}\text { 9. a AIDS passou a ocupar grandes espaços nos jornais e revistas e nos noticiários de rádio } \\
\text { e televisão (AIDS started to occupy spaces in magazines and newspapers and in } \\
\text { news on radio and television) }\end{array}$ \\
\hline \multirow{3}{*}{ CD4 } & $\begin{array}{l}\text { 1. cooperação entre linfócitos } T C D 4+\text { e linfócitos } B \text { (cooperation between lymphocites } \\
\text { T CD } 4+\text { lymphocites B) }\end{array}$ \\
\hline & $\begin{array}{l}\text { 2. linfócitos CD4 que informam algo tardiamente (lymphocites CD4 that informe } \\
\text { something late) }\end{array}$ \\
\hline & $\begin{array}{l}\text { 3. os alvos preferenciais são as células } C D 4+\text { de memória (the preferential targets are } \\
\mathrm{CD} 4+\text { cells of memory) }\end{array}$ \\
\hline
\end{tabular}

The examples related to the term HIV are also particularly illustrative, among many others chosen by the author. Let us take a look at two of them:

a) o HIV não é o único nem será o último patógeno a trazer transtornos e questionamentos aos trabalbadores da saúde e à humanidade em geral ( HIV is not - or will be - the last pathogen to bring inconvenience and questions to health workers and to the humankind in general);

b) envelope do HIV-1 (HIV-1's envelope).

The description of a multifaceted object such as metaphor tends sometimes to ask for subjective criteria, such as difference in meaning, culture, etc. The whole time, one has the impression that the boundary between polysemy, metaphorical sense, figurative and literal/denotative sense is very tenuous. We can not deny that these interfaces also lead to some 
difficulties, for Huang as well, in the identification of what is effectively metaphoric in PMEs. Some of them were confused, as Huang said, being "dead metaphors", which are no longer perceived as metaphors, or even as metonymy.

In the midst of 2,578 contexts taken from a corpus of papers extracted from the most prestigious medical Brazilian journals, 90 patterns of metaphors were identified and divided into seven major groups. These groups of metaphors, inspired by Lakoff \& Johnson (2002), were:

a) Metaphor of personification - an X element, not animated, acquires human traits: TERM: AIDS

a AIDS está ganbando a corrida (AIDS is winning the race)

b) Metaphors of personification with attribution of capacity - same as above, but with an indication of ability or strength:

TERM: VIRUS

o virus parece capaz de infectar as células que não a expressam em sua superfície (the virus seems capable to infect cells that do not express it in the surface)

c) Metaphor of time - refers to any expression of time, featuring a chronological period:

TERM: AIDS

tempos de AIDS (times of AIDS)

d) Metaphor of process - indicates the occurrence or a sequence of a phenomenon:

TERM: AIDS

historia natural da AIDS (natural history of AIDS)

o uso de drogas (...) poderia acelerar o curso da AIDS (the use of drugs [...] could accelerate the course of AIDS)

e) Metaphor of container - it implicates an imaginary container, because it represents a certain amount or variation of or in this container.

TERM: CORTISOL

reserva de cortisol (cortisol reserve)

f) Orientational Metaphor - expresses a direction for an element or phenomenon: TERM: AIDS

a AIDS passou a ocupar grandes espaços nos jornais e revistas e nos noticiários de rádio e televisão (AIDS started to occupy spaces in magazines and newspapers and in news on radio and television)

g) Metaphor of war - it involves conflict, invasion or animosity between two elements or entities: 
TERM: AIDS

será porque a AIDS atingiu mortalmente personalidades mundanas? (is it because AIDS killed mundane personalities?)

Having bravely faced the challenge of detecting different kinds of metaphors and recognizing their expressive variations over an entire universe of quite technical texts, the author concludes:

As stated by Lakoff \& Johnson (2002), metaphors "infiltrate" human life in such an intense way that we do not even notice it, since they structure extremely important (and often imperceptible) processes, like the process of cognition and comprehension of the world. In this perspective, metaphors are inherent in the constitution of scientific knowledge and its expression, and they are also not perceptible to the "naked eye" (HUANG 2005: 76).

Finally, the author suggests that the metaphors of personification, almost half of the expressions identified, seem to point to a relation of power associated to the statements examined: the terms related to diseases have, in almost half of the cases, human traits. Furthermore, the author shows us that metaphors of personification with capacity attribution around terms related to diseases may contribute to a vision of patient's victimization. So, in synthesis, AIDS is capable of $\mathrm{X}$, while patient suffers, usually, of $\mathrm{Y}$ or of $\mathrm{Z}$.

\section{A FEW CONSIDERATIONS, CHALLENGES AND PROSPECTS}

As easily seen by the synthesis of Huang's work (2005), the observation of metaphorization in medical texts goes far beyond a verification of stylistic elements in a way that considers metaphors as "ornaments" of rhetoric. Even though the author's choice was to verify metaphors which were only around terms or expressions, taken a priori as more relevant and, in the end, demonstrated not to be abundant, since 25 of the 113 terms examined were confirmed, we see the relevance of such research in the insights it brings on the conceptual framework surrounding AIDS in a scientific text corpus.

A work such as this inspires new studies and shows that the terminologies reveal, indeed, metaphoric associations in their denominations and definitions (or explanations). What conformation of conceptual system 
is associated with the alternations of expressions such as pacientes com aids (patients with aids) and pacientes de aids (patients of aids)? This is the question the author has raised. And if, as indicated by Lakoff \& Johnson (2002), metaphors are everywhere and in every part of the language in use, it will be an important challenge to establish a cut or an initial territory so that we may explore them systematically. From that initial point, and others that will follow the days of research, we believe it is possible to foresee its "geography." It should be possible to infer an overview of metaphorization in the midst of the languages of sciences and technologies.

Finally, it can still be said that the study of metaphors in Terminology reveals the fact that terminologies, taken separately, show us a little about the facet of specialized languages. If the text is the habitat of terminologies, taking this sentence as a metaphor, it is time to invest in the idea of descriptive and critical appreciation of an entire linguistic and cognitive environment of technical-scientific communication. The complexity of the issue, the huge challenge to recognize, critically, what is or what is not metaphoric and its variations just makes it more instigating and necessary.

Recebido em agosto de 2009 Aprovado em fevereiro de 2010 E-mail:mfinatto@terra.com.br

\section{REFERENCES}

Bunge, Mario. 1961. Causalidad. Buenos Aires: Sudamerica.

D’OnOfrio, Salvatore. 1980. Concepção retórica e concepção semântica da metáfora. Alfa 24:149 -156. São Paulo.

Finatto, Maria José Bocorny. 2001. Definição terminológica: fundamentos teórico-metodológicos para sua descrição e explicação. Porto Alegre: UFRGS. Tese de doutorado.

Huang, Carolina. 2005. A metáfora no texto científico de Medicina: um estudo terminológico da linguagem sobre AIDS. Porto Alegre: UFRGS. Dissertação de mestrado.

Lakoff, George \& Mark Johnson. 2002. Metáforas da vida cotidiana. São Paulo: Educ/ Campinas: Mercado de Letras. 
Lopes, Edward. 1987. Metáfora: da retórica à semiótica. São Paulo: Atual. Schaff, Adam. 1968. A philosophy of man. New York: Deltabook.

Temmerman, Rita. 2000. Towards new ways of Terminology description: the sociocognitive approach. Amsterdam/Philadelphia: John Benjamins. 